\title{
Infrastructural Facility and the Students' Academic Performance - A Critique
}

\author{
Adejompo Fagbohunka
}

Received:16 072016 / Accepted: 1410 2016 / Published online: 31062017

(c) 2017 Faculty of Geography UGM and The Indonesian Geographers Association

\begin{abstract}
The paper underscores the infrastructural facility and the student's academic performance in Adekunle Ajasin University, Akungba Akoko, Ondo State, Nigeria. Thirty questionnaires were administered through a systematic sampling technique in each of the six faculties making a total of 180 questionnaires. The paper has found out a positive relationship between the student's academic performance, power supply and health facilities. However, the internet facilities and transportation facilities were not adequate, whereas water supply was adequate. A test of the impact of infrastructural facility on the student's academic performance, using a Chi Square statistical technique revealed a significant value of 177.1 at $0.05 \%$ level. The paper recommends that the existing facilities should be upgraded and significantly improved by the government; urgent attention should be given to the development of the internet facilities and transportation sector of the University. Also, private partnership should be encouraged in the infrastructural development of the University.
\end{abstract}

Keywords: Academic performance, Infrastructural facility, Students, University

\begin{abstract}
Abstrak Makalah ini membahas mendasar tentang fasilitas infrastruktur dan prestasi akademik siswa di Universitas Adekunle Ajasin, Akungba Akoko, Ondo State, Nigeria. Tiga puluh kuesioner diberikan melalui teknik sampling sistematis di masing-masing dari enam fakultas yang menghasilkan total 180 kuesioner. Makalah ini telah menemukan hubungan positif antara kinerja akademik siswa, fasilitas catu daya dan kesehatan. Namun, fasilitas internet dan sarana transportasi tidak memadai, padahal pasokan air sudah memadai. Uji dampak fasilitas infrastruktur terhadap prestasi akademik siswa, dengan teknik statistik Chi Square menunjukkan nilai signifikan 177,1 pada tingkat 0,05\%. Makalah ini merekomendasikan agar fasilitas yang ada harus ditingkatkan dan ditingkatkan secara signifikan oleh pemerintah; Perhatian mendesak harus diberikan pada pengembangan fasilitas internet dan sektor transportasi Universitas. Selain itu, kemitraan swasta harus didorong dalam pengembangan infrastruktur Universitas.
\end{abstract}

Kata kunci: Mahasiswa, Kinerja Akademik, Sarana Infrastruktur, Universitas

\section{Introduction}

Infrastructure plays a very important role in the growth process of an economy; thereby raising the level of productivity and also leads to a higher potential level of output for the future Infrastructure refers to the fundamental facilities and systems serving a country, city, or area, including the services and facilities necessary for its economy to function. Infrastructural development involves fundamental structures that are required for the functioning of a community and society. This is usually referred to as structures like roads, water supply, sewers, electrical grids, telecommunications, renewable energy, and so on [Abosedra etal, 2009; Mandel, 2008; Frischmann, 2007; CBN, 2003; Pendse, 1980].

There is actually a general belief that the condition of school's learning environment, especially infrastructure has an important impact on studentsacademic performance and effectiveness. The facilities that are needed to facilitate effective learning in an educational institution include adequate power and water supply,

\footnotetext{
Adejompo Fagbohunka

Geography and Planning Sciences Department, PMB 001, Adekunle Ajasin University, Akungba Akoko, Ondo State, Nigeria.

Corresponden email: adejompofagbohunka@gmail.com
}

good communication system, improved transportation system, adequate classrooms, libraries, laboratories as well as furniture items and sporting equipment. The quality of infrastructure has strong influence on the academic standard which is an index of quality assurance in the school. For instance, Earthman [2002], reporting on California, revealed that comfortable classroom temperature and smaller classes enhance students effectiveness and provide opportunities for participation more fully in discussions, reduce discipline problems and thereby enhanced better performance than students in schools with substandard buildings by several percentage points.

Sustainable economic growth often occurs in an environment where there is a meaningful infrastructural development, and there is evidence that it reduces inequality in the society. It is also clear that development of infrastructure (energy, transport, water, ICT among others) generally contributes significantly to the level and quality of development of an area. University wield tremendous importance to the socio-economic transformation of any region, because knowledge is power, knowledge liberate from ignorance and poverty to all round social economic development. Some impacts expected of a university region are numerous; ranging from employment 
creation, increase housing units to improve adequate infrastructure facilities. Adequate infrastructural facility is therefore a pre-requisite for running these Universities and also for the student to be able to hit the ground running academically. An underdeveloped region can be developed through the establishment of a University, thereby posing a great value to the overall development of such area.

The contribution of infrastructural facility to economic development is enormous, since it provides the environment for productive activities to take place, encourage investment, allows wider movement of goods and people facilitates information flows and helps commercialize and diversify the economy [World Bank, 1994]. The quest for adequate infrastructure in Nigeria tertiary education sector cannot be abandoned because it is the bedrock of development and highly needed for successful, standard and quality education. Infrastructure development can reduce stress and promote good health. It will also reduce crime level. Infrastructure has always played a key role in integrating economies within a region. Well developed and efficient infrastructure is essential for a region's economic development and growth. In a dynamic concept, infrastructure is seen as a regional public good that moves factors of production within and across countries, thus helping the region attain higher productivity and growth.

Infastructure can have a strong impact on the incidence and depth of poverty by supporting inclusive growth, i.e., economic growth that can facilitate a meaningful and sustainable poverty reduction [World Bank, 2009]. Research on infrastructure dwells on different issues such as education, roads, water supply, power grids, telecommunication and hospitals [Abosedra et al. 2009; Mandel, 2008; Frischmann, 2007; CBN 2003; Pendse, 1980]. According to Kathmandu Final Workshop Report [2009], infrastructure can help solve four problems: social; health and environment; development; and, economics. Abosedra etal [2009] stated that infrastructure development involves fundamental structures that are required for the functioning of a community and society.

The importance of infrastructural services to economic development is enormous. As observed by Fox [1994], Jimenez [1994], World Bank [1994], Lanjouw [1995], and ADB [2009] infrastructure provides the conducive environment for productive activities to take place and facilitate the generation of economic growth. For instance, in the absence of adequate power supply, water, transportation and communication facilities, production process or location advantages may not be optimized. On the other hand, availability of an efficient infrastructure network can stimulate new innovation in the other sectors.

\section{The Methods}

Akungba-Akoko is situated in Akoko southwest local government area of Ondo-state in south western part of Nigeria. It is the community in which Adekunle Ajasin University is located. It's geographical coordinates are latitude $7^{\circ} 24^{\prime} 0$ and $7^{\circ} 28$ ' 0 'North, and longitude $5^{\circ} 44^{\prime}$ ' 0 ' and $5^{\circ} 45^{\prime} ' 0$ ' East. The town is surrounded by little hills and bounded by some towns such as Ikare in the North, Oka in the East, Etioro in the South, and Supare in the West.

Adekunle Ajasin University, Akungba-Akoko was established in March 1982 by the government of the old Ondo State, headed by the late Chief Adekunle Ajasin. At present, Adekunle Ajasin University AkungbaAkoko (AAUA) has a well over 10,000 students, and over 1,200 staff - academic and non-academic - and six Faculties - Arts, Education, Law, Science, Social and Management Sciences and Agriculture.

Data was collected through a systematic random sampling technique. First, five departments in each of the six faculties were randomly sampled, while six questionnaire was administered in each of these department. On the whole thirty questionnaires were administered in each of the six faculties, making a total of one hundred and eighty. Secondary data were also employed and the data analyzed descriptively and inferentially.

Table 1 shows the socio-economic characteristics of the respondents, $108(60 \%)$ were males, while 72(40\%) were females. Also, 83(46\%) were between 18 and 28 years, whereas $23(13 \%)$ were above 40 years. Furthermore, 24 (13\%) were in 100 level, while 50 (28\%) were in 300 level; another 22(12.2\%) were in 500 level. One hundred and twelve respondents are Christian, whereas $7(04 \%)$ were involved in traditional religion.

Table 2 depicts the influence of power supply on the student's academic performance, 79 (44\%) respondents opined very satisfactory, whereas 36 (20\%) opined not satisfactory; another, 19 (10\%) agreed averagely satisfactory. It is therefore, apparent that power supply has a positive influence on the student's academic performance.

Figure 1 reveals the effects of internet facilities on the student's academic performance, (12 6.6\%) believed that the internet facilities has very significant effect, whereas $126(70 \%)$ were of the opinion that it the internet facilities has contributed insignificantly to the students performance academically.

Table 3 reveals that 141 (78\%) respondents agreed that water supply has a very adequate contribution to the student's academic performance, whereas only $1(1 \%)$ opined grossly inadequate.

Figure 2 shows that 139(77\%) respondents believed that the health facilities has led to the student's academic excellent performance, whereas $05(03 \%)$ were of the opinion that the impacts of health facilities was fair. 
Indonesian Journal of Geography, Vol. 49 No. 1, June 2017 : 11 - 16

Table 1. Socio-Economic Variables of the Respondents

\begin{tabular}{|c|c|c|}
\hline \multicolumn{3}{|c|}{ Gender } \\
\hline Sex & Number of respondents & Percentages \\
\hline Male & 108 & 60 \\
\hline Female & 72 & 40 \\
\hline Total & 180 & 100 \\
\hline \multicolumn{3}{|l|}{ AGE (Years) } \\
\hline$<18$ & 45 & 25 \\
\hline $18-28$ & 83 & 46 \\
\hline $29-39$ & 29 & 16 \\
\hline Above 40 & 23 & 13 \\
\hline Total & 180 & 100 \\
\hline \multicolumn{3}{|l|}{ Levels } \\
\hline 100 & 24 & 13 \\
\hline 200 & 40 & 22.2 \\
\hline 300 & 50 & 28 \\
\hline 400 & 44 & 24.4 \\
\hline 500 & 22 & 12.2 \\
\hline Total & 180 & 100 \\
\hline \multicolumn{3}{|l|}{ Religion } \\
\hline Christianity & 112 & 62 \\
\hline Muslim & 61 & 34 \\
\hline Traditional & 07 & 4 \\
\hline Total & 180 & 100 \\
\hline
\end{tabular}

Table 2. Influence of Power supply on Students Academic Performance

\begin{tabular}{lll}
\hline Effects & $\begin{array}{l}\text { Number of } \\
\text { Respondents }\end{array}$ & Percentages \\
\hline Very satisfactory & 79 & 44 \\
Satisfactory & 46 & 26 \\
Averagely Satisfactory & 19 & 10 \\
Not satisfactory & 36 & 20 \\
Total & 180 & 100 \\
\hline
\end{tabular}

Field Survey, 2015

Table 3. Water Supply and the Students Academic Performance

\begin{tabular}{lll}
\hline Effects & $\begin{array}{l}\text { Number of Re- } \\
\text { spondents }\end{array}$ & $\begin{array}{l}\text { Percent- } \\
\text { ages }\end{array}$ \\
\hline Very Adequate & 141 & 78 \\
Adequate & 25 & 14 \\
Inadequate & 13 & 07 \\
Grossly Inadequate & 1 & 1 \\
Nil & - & \\
Total & 180 & 100 \\
\hline
\end{tabular}

Table 4. Students Academic Performance and the Transportation System

\begin{tabular}{lll}
\hline Effects & Number of Respondents & Percentages \\
\hline Positive & 23 & 13 \\
Negative & 126 & 70 \\
Nil & 31 & 17 \\
Total & 180 & 100 \\
\hline
\end{tabular}

Field Survey, 2015.

Table 4 shows that $126(70 \%)$ respondents asserted that there has been a negative relationship between the student's academic performance and the transportation system, while 23(13\%) believed that positive relationship exists between the student's academic performance and the transportation system

Table 5. Adequacy of Infrastructural Facilities in Adekunle Ajasin University

\begin{tabular}{lll}
\hline Adequacy & Number of Respondents & Percentages \\
\hline Adequate & 78 & 43.3 \\
Inadequate & 96 & 53.3 \\
Nil & 06 & 03.3 \\
Total & 180 & 100 \\
\hline
\end{tabular}

Field Survey, 2015. 
Figur 1. Internet Facilities and the Students Academic Performance

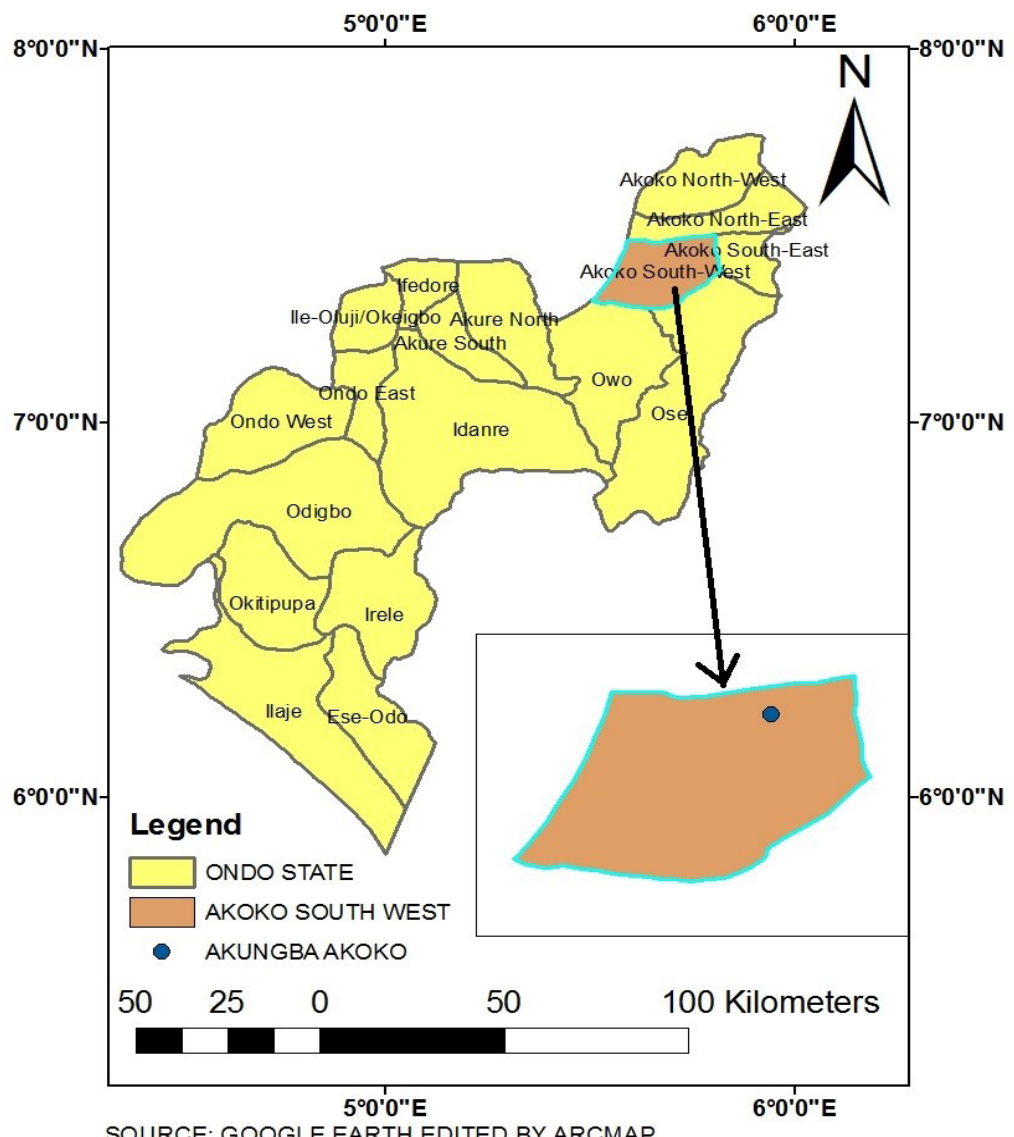

Source: Ministry of Lands and Housing, Akure, 2013

Figure 2. The Impacts of Health Facilities on Students Academic Performance

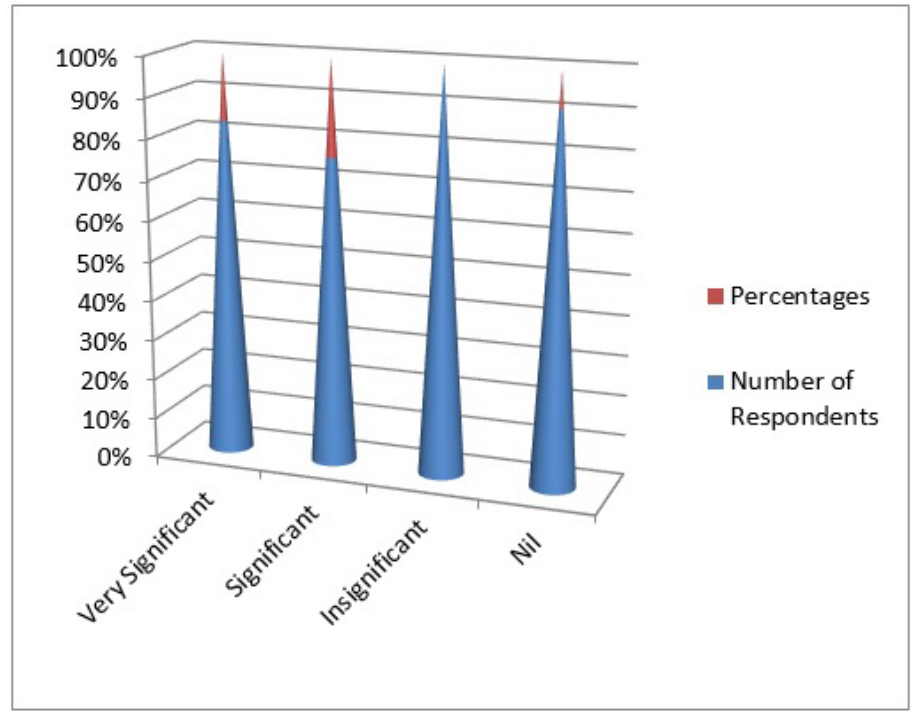

Field Survey, 2015. 
Table 5 shows the adequacy of infrastructural facilities in Adekunle Ajasin University, out of $180(100 \%)$ respondents, $96(53.3 \%)$ opined inadequate, whereas $78(43.3 \%)$ agreed that infrastructural facilities is inadequate.

Figure 3 shows that $38(21 \%)$ respondents opined an excellent academic performance of students as a result of infrastructural facilities, whereas 59(33\%) believed that infrastructural facilities have a fair effects on students performance. Another, 10(5\%) agreed that infrastructure has impacted poorly on the student's academic performance.

Table 6. Chi- Square Test on the Effect of Infrastructural Facilities on Students Academic Performance

\begin{tabular}{llllll}
\hline Option & $\mathrm{O}$ & $\mathrm{E}$ & $\mathrm{O}-\mathrm{E}$ & $(\mathrm{O}-\mathrm{E}) 2$ & $(\mathrm{O}-\mathrm{E}) 2$ \\
\hline \multicolumn{1}{c}{$\mathrm{E}$} & & & & & \\
Excellent & 38 & 90 & 52 & 2704 & 30 \\
Very good & 46 & 90 & 44 & 1936 & 21.5 \\
Good & 27 & 90 & 63 & 3969 & 44.1 \\
Fair & 59 & 90 & 31 & 961 & 10.7 \\
Poor & 10 & 90 & 80 & 6400 & 71.1 \\
& & & & & 177.4 \\
\hline
\end{tabular}

The Chi-Square test carried out in table 6 on the effects of infrastructural facilities on the student's academic performance has revealed Calculated ChiSquare value 177.1 and tabulated Chi-Square value 15.815. This further lends credence to the fact that infrastructural facilities have a positive relationship to the academic performance of students in Adekunle Ajasin University, Akungba Akoko.

\section{Conclusion}

The paper has examined the influence of infrastructural facilities on the student's academic performance of Adekunle Ajasin University Akungba Akoko. Universities play a crucial role in society as producers and transmitters of knowledge, teaching and research which is the most important function of university leads to development in diverse ways. It must be noted that the teaching and research could be effectively enhanced under conducive atmosphere of adequate infrastructural facilities. The paper has revealed a significant positive relationship between power supply and the student's academic performance. The research further revealed that the following infrastructural facilities such as, water supply and the health facilities have contributed tremendously to student's performance.

The paper shows that infrastructural facilities like, the internet facilities and transportation has insignificant contribution to the student's academic performance. Despite the fact that research reveals inadequacy of infrastructural facilities, the chisquare test carried out on the effects of infrastructural facilities on the student's academic performance at 0.05 significant levels reveals a calculated chi square value of 177.1 compared to the tabulated chi-square value of 15.82. This connotes that infrastructural facilities has positively affected the student's academic performance.

Despite the role of University in knowledge transfer activities and its contribution to economic development, infrastructural facilities has been one of the major clog in the wheel of meaningful contribution of Universities to regional socio economic revamping. The paper has revealed that much is still needed to be done in two critical areas of transportation and the internet facilities, in this era of globalization adequate internet facilities is very germane, as it will enhance the

Figure. 3 Effects of Infrastructural Facilities on Students Academic Performance

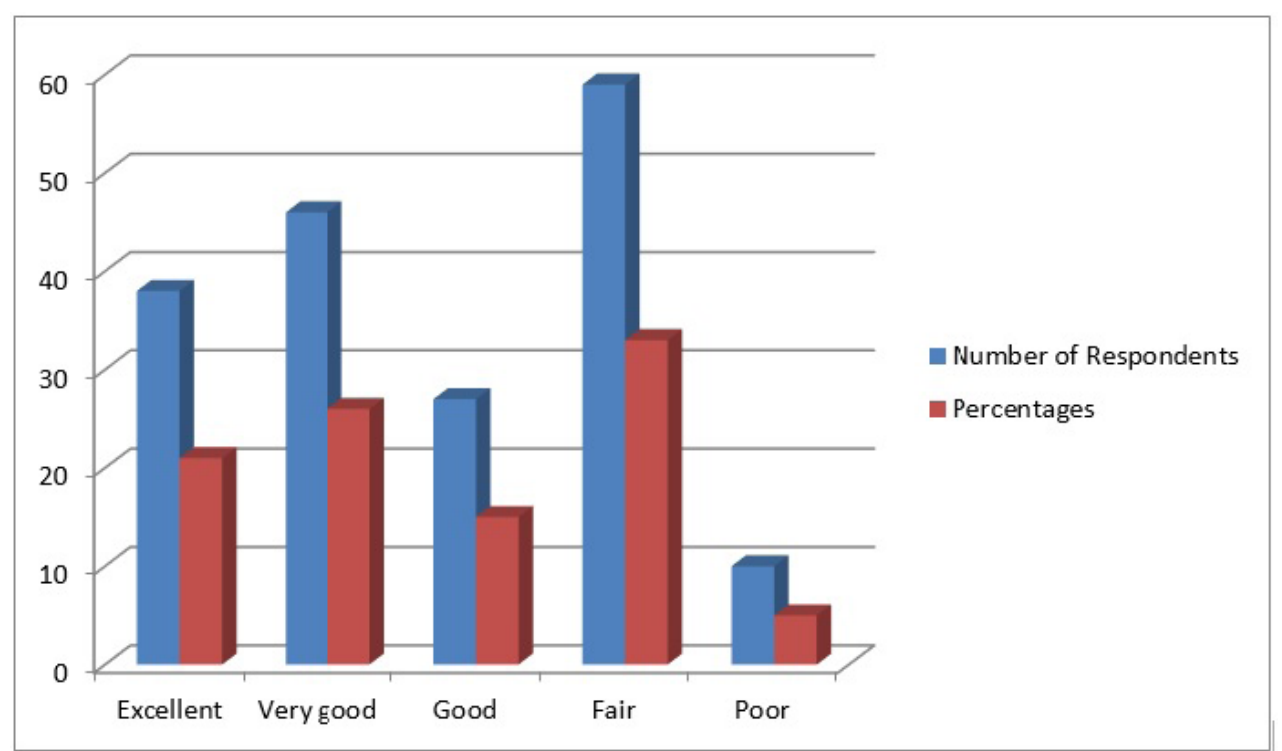

Field Survey, 2015. 
students to favourably compete with their counterparts in any part of the world.

The student's performance, contribution to socio economic development, ability to compete excellently in the technological world is hinged on infrastructural facility development. It is therefore, recommended that the government should be more concerned, involved and invested on the infrastructural facilities in the University. The University management should try to secure a private partnership in infrastructural development and must in turn adequately maintained the existing infrastructural facilities, while the students also needs to be sensitized on the need to maintain the existing infrastructural facilities on campus.

\section{References}

Abosedra, S. (2009). Electricity Consumption and Economic Growth: the Case of Lebanon, in Applied Energy 86(4): 429-432.

Africa Development Bank (ADB) (2009). An Overview of the Infrastructure Strategy Including MTS. ADB, Abidjan, Ivory Coast.

Ayeni, A.J. et al. (2012). Improving learning infrastructure and environment for sustainable quality assurance practice in secondary schools in Ondo State, South-West, Nigeria. International Journal of Research Studies in Education, Volume 1 Number 1, 61-68.

Central Bank of Nigeria (CBN)(2003).Highway Maintenance in Nigeria: Lessons from other Countries', Research Occasional Paper, 27.

Deepika, G. (2002). Impact of Infrastructure on Productivity: Case of Indian Registered Manufacturing. Centre for Development Economics; Working Paper No. 6.

Earthman, G. I. (2002). School facility conditions and student academic achievement. Los Angeles: University of California's Institute for Democracy, Education and Access. (http://www.ucla-idea.org).

Frischmann, B.M. (2007). An Economic Theory of Infrastructure and Commons Management in Minnesota Law Review, 89(917).

Fox W.F. (1994). Strategic Options for Urban Infrastructural Management, UNDP/UNCHS/. World Bank Urban Management Progress, No. 6

Gafar, T. and Saad, B. (2009). An Empirical Analysis of the Long-Run Effect of Infrastructure on Industrialization in Nigeria. Journal of International economic Review, 2:12(2009):135-149.

Jimenez, F. (1994). Human and Physical Infrastructure: Public Investment and Pricing Policies in Developing Countries, World Bank Policy Research Working Paper No. 1281

Lanjouw, P. (1995), Infrastructure: A Ladder for the Poor: IMF/ World Bank Finance and Development, 32(1), 3335.

Mandel, G.W. (2008). When to open infrastructure access', in Ecology Law Quarterly, 35(2): 205-214.

Pendse, D.R. (1980).Energy Crisis and its Impact on Energy Consumers in the Third World:Economic and Political Weekly, 15(4): 175-184.

World Bank (1994). Infrastructural for Development, World Development Report, New York: Oxford University Press 